\title{
GLOBAL AND LOCAL CONTRADICTIONS: FUNDUMENTALISM VERSUS GLOBALIZATION
}

\section{B. R. Mogilevich}

Saratov State University

E-mail: mogilevich@sgu.ru

The article deals with characteristic features of the main contemporary opposition: fundamentalism and globalism as main contemporary opponents. The two main approaches to globalization phenomenon interpretation are presented. The new type of socialization in a global community is characterized. The new theories of new order images, explaining the causes of social inequality and countries' dependence on each other are described.

Key words: social transformations, dependence, global socialization, social inequality, world order images, fundamentalism, globalization.

Глобальные и локальные противоречия: фундаментализм против глобализации

\section{Б. Р. Могилевич}

В статье рассмотренны основные характеристики главного противостояния современности: фундаментализма и глобализма как основных оппонентов. Представлены два основных подхода к пониманию феномена глобализации. Дана характеристика нового типа социализации в глобальном обществе. Описаны новые теории образов мирового порядка, объясняющее причины социального неравенство и зависимости стран друг от друга.

Ключевые слова: социальные трансформации, зависимость, глобальная социализация, социальное неравенство, образы нового мира, фундаментализм, глобализация.

\section{DOI: 10.18500/1818-9601-2017-17-3-262-264}

According to A. Giddens, the modern period is characterized by staggering social transformations ${ }^{1}$. These objective tendencies influence the ways of life worldwide. Globalization changed people's lifestyles in all aspects. The term "globalization" came into being in the nineties of the twentieth century. There exist two approaches to this concept interpretation: skeptical and radical. The skeptical approach considers that globalization doesn't present anything new in comparison with the former periods of human civilization, the national income of many countries not depending on global cooperation. On the contrary, the radicals are of opinion that globalization penetrates into all spheres of human activity. Moreover, national governments experience a significant lack of their power due to world market development. The majority of globalization opponents proclaim the appearance of the two worlds - "the winners" and "the defeated". All their contradictions are based on economic inequality between the de-

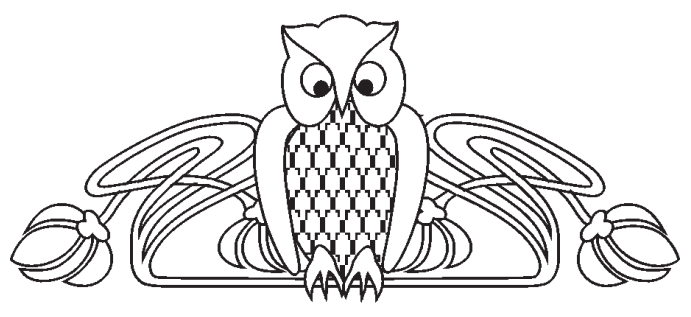

veloped and developing countries. Nevertheless, globalization can't be considered as an unexpected phenomenon. It is rooted in significant social transformations - the Industrial and Electronic Revolutions, the formation of Common Labor Market, worldwide migration and unprecedented scale of international socio-cultural cooperation. The sociological context of globalization focuses on peoples everyday life social changes, resulting in unification of their lifestyles. Electronic devices of socio-cultural communication gave rise to the appearance of a new phenomenon - global culture, its main characteristics being transnationalization of peoples lives ${ }^{2}$. The growth of urban population, especially hired workers, led to unified lifestyles' rhythms - many new various social contacts, types of activity, sources and means of getting information came into existence. These social transformations influenced behavioral and moral norms, as well. For example family, marriage, and education models. Global culture promoted a new type of socialization - a global one, with a lot of variants: a liberal one - a Weber type social actors possess concrete goals, strive for success and rational individual activity in the frames of law and discipline ${ }^{3}$. In this case individuals are open to all innovations and are able to respond to globalization challenges and risks ${ }^{4}$.

The second type of global socialization is based on the ideas of solidarity and stability in the frames of A. Durkheim's theories (a Durkheim's type of social actors) ${ }^{5}$. Weber's ideas are embodied in the global concept, while Durkheim's ones reflect the local neglection of globalization.

The modern context of social communication can be defined as a permanent process of Weber's and Durkheim's types of socialization opposition. Globalization brings about numerous challenges which are quite difficult to overcome. For example, economic and socio-cultural challenges of global warming, ecological disasters, propagation of infectious diseases. In the course of globalization studies, A. Giddens came to the conclusion that traditions are always used as a powerful antiglobalization weapon. The thing is, that everyday life traditions are always more conservative than institutional ones. Globalization, global culture in particular, gives rise to the processes to detraditionalization in all spheres of human life. They provide an individual with freedom of choice and self-ac- 
tivity which demand permanent self identification actions. On the other hand, global detraditionalization leads to serious contradictions between globalism and fundamentalism, the latter insisting on the ideas of devotion to the roots in all spheres of human activity: social, political, economic ones. A. Giddens with great wit defined fundamentalism as "traditions under siege",

Undoubtedly all modern social transformations turn humankind into a unified social aggregate. Earlier the world consisted of separate association units, from a tribe to a national state, each with its own identity. At present there appeared a lot of supernational units, for example European Union, European Parliament, Interpol, NATO, UN ${ }^{7}$.

The Electronic Revolution, in mass media in particular, contributed to modern social reality uniformity. These modern socio-cultural transformations of various types come into being, develop and function beyond the frames of national states. Besides, these transformations turned out to be possible due to the appearance of new social actors, challenges and goals ${ }^{8}$.

The sociological approach to these problems resulted in creation of some theories, aimed at revealing the causes of social inequality and growing countries dependence on each other - according to imperialism theory, social inequality turns out to be the very essence of capitalism, its main goals being to get cheap labor power and to widen sale markets. In this connection the whole world acquires asymmetric characteristics - a few developed countries exploit less developed ones, which results in the growth of social inequality.

The dependence theory is concerned with the interrelations between various national states in the period after the fall of the colonial system. Many former colonies were not able to get rid of economic dependence from their former metropolis. This dependence is caused by the inequality of the center (former metropolis) and the periphery (former colonies), as national incomes of former colonies provide former metropolis with cheap labor. To get rid of this kind of dependence, the periphery must join common world economics by creating its own technologies and industries ${ }^{9}$. Such countries as Singapore, South Korea, Congo, can be serve as good examples.

The theory of "world system" turned out to be very productive in considering global social changes. According to this theory, all social global transformations can be divided into three periods: the period of mini systems with common culture and strict labor division (pre-agrarian epoch); the period of mini empires, formed in the course of uniting mini systems with strict administration, taxation, and agrarian dominance in the economy. This period is characterized by permanent wars, aimed at capturing alien territories.

The period of world economy, beginning in the sixteenth century, the main characteristic fea- ture of this period is the Market, the state providing the conditions for successful market relations ${ }^{10}$.

Globalization process is inseparable from culture development. According to P. Sorokin, culture is a process of communication, and its participants depend on each other's cultural level development. World culture is presented by two separate types: speculative and sensual with an idealistic one as intermediate. The speculative culture is characterized by the dominance of the spiritual over the material in all spheres of human activity. The sensual culture adheres to the prevalence of material values, which exist in the outer world, the circumstances influencing moral principles. Nevertheless, these types do not exist as separate and pure ones. They are combined in an idealistic type of culture, containing material and spiritual natural qualities, which provide a creative individual with an activity for further self improvement and making the quality of life better worldwide. These cultural cycles replace each other, depending on the level of their creative potential exhaustion, conditioned by internal and external factors ${ }^{11}$.

In other words, the variety of cultural cycles and systems under globalization brings about both distrust and prosperity. In spite of the variety of approaches to globalization studies, there does not exist a concrete and clear solution to numerous social problems. However, it is of no doubt that global content is becoming natural and productive in its local forms.

The inevitability of globalization presents as benefits as well as dangers to mankind. A new "theory of world order images" strives to explain the nature of global and anti-global movements tendencies. The first image is Global Union I, consisting of community of independent states, each one with it's own cultural and institutional system. This type of world order presumes anti-global tendencies in terms of fundamental (traditional) ideas. Global Union II reflects the idea of global community, aiming at achieving common goals and values. This type of world order is embodied in various global, ecological and antiterrorist organizations ${ }^{12}$.

Thus the modern global social reality is characterized by severe contradictions between fundamentalism and detraditionalization. Various theories of global world order aim at overcoming the contradictions of global and local contexts of humankind lifestyles worldwide.

\section{Примечания}

1 См.: Giddens A. Introduction to Sociology. New York, 1993. P. 3.

2 См.: Могилевич Б. Р. Коммуникационное взаимодействие глобальной и локальной культур // Социология. Журнал российской социологической ассоциации. 2010. № 2. С. 156-162.

3 См.: Вебер М. Протестантская этика и дух капитализ- 
ма // Вебер М. Избр. произведения : пер. с нем. М., 1990. C. $87-89$.

4 См.: Поппер К. Отрытое общество и его враги. М., 1992. C. 67.

5 См.: Дюркгейм Э. О разделении общественного труда. М., 1996. С. 18.

6 Гидденс Э. Ускользающий мир : как глобализация меняет нашу жизнь. М., 2004. С. 63.

7 См.: Штомпка П. Социология социальных изменений. M., 1996. C. 70.
8 Там же. C. 122

9 См.: Cardoso F. Dependency and Development in Latin America. Berkley, 1969. P. 163.

10 См.: Валерстайн И. Анализ мировых систем и ситуации в современном мире. М., 2001. С. 18-19.

11 См.: Сорокин П. Кризис нашего времени : социальный и культурный обзор. М., 2009. С. 87-95.

12 См.: Robertson R. Globality Global Culture and Images of World Order. Habercamp and Smelser, 1992. P. $395-411$.

\section{Образец для цитирования:}

Mogilevich B. R. Global and Local Contradictions: Fundumentalism Versus Globalization // Изв. Сарат. ун-та. Нов. сер. Сер. Социология. Политология. 2017. Т. 17, вып. 3. С. 262-264. DOI: 10.18500/1818-9601-2017-17-3-262-264.

\section{Cite this article as:}

Mogilevich B. R. Global and Local Contradictions: Fundumentalism Versus Globalization. Izv. Saratov Univ. (N. S.), Ser. Sociology. Politology, 2017, vol. 17, iss. 3, pp. 262-264. DOI: 10.18500/1818-9601-2017-17-3-262-264. 